\title{
Improvement ability of male parent by gibberellic acid application to enhancing the outcrossing of cytoplasmic male sterility rice lines
}

\author{
Hassan HAMAD ${ }^{1}$, Elsayed GEWAILY ${ }^{1}$, Adel GHONEIM ${ }^{2,3}$, Mohamed SHEHAB ${ }^{1}$, Neama EL-KHOLLY
}

Improvement ability of male parent by gibberellic acid application to enhancing the outcrossing of cytoplasmic male sterility rice lines

Abstract: The study quantified the effect of gibberellic acid $\left(\mathrm{GA}_{3}\right)$ as a pre-flowering treatment for male parent Giza $178 \mathrm{R}$ and the influence of male to female ratio (2R:10A, 2R:12A, 2R:14A and 2R:16A) between male (R) to female (A) for two Cytoplasmic Male Sterility (CMS) lines ('IR69625' and 'G46') on hybrid rice seed production. The main plots were occupied by CMS lines while; GA3 application for male parent Giza 178R were arranged in the sub plots and male to female ratio was arranged in the sub-sub plots. The results indicated that, the, duration of floret opening, angle of floret opening, filaments exsertion, filaments length, anther length, plant height and number of tiller hill ${ }^{-1}$ of male parent Giza $178 \mathrm{R}$ were significantly at $300 \mathrm{~g} \mathrm{GA}_{3} \mathrm{ha}^{-1}$ concentration. Plant height, panicle exsertion, panicle length, flag leaf angle and 1000-grain mass of CMS were not significantly affected by the $\mathrm{GA}_{3}$ application for male parent and male to female ratio, while, number of fertile panicles hill ${ }^{-1}$, panicle mass, seed set, seed yield and harvest index of CMS lines were highly significantly affected. The highest seed yield (2.880 and $\left.2.950 \mathrm{t} \mathrm{ha}^{-1}\right)$ was obtained by CMS line IR69625A using $300 \mathrm{~g} \mathrm{GA}_{3} \mathrm{ha}^{-1}$ of male parent Giza $178 \mathrm{R}$ with male to female ratio of $2 \mathrm{R}: 14 \mathrm{~A}$ during both seasons.

Key words: hybrid rice production; cytoplasmic male sterile lines; gibberellic acid $\left(\mathrm{GA}_{3}\right)$; male to female ratio; panicle exsertion
Received February 22, 2021; accepted June 17, 2021. Delo je prispelo 22. februarja 2021, sprejeto 17. junija 2021
Izboljševanje sposobnosti moških staršev z giberilinsko kislino za pospeševanje navskrižnega križanja citoplazmatsko moško sterilnih linij riža

Izvleček: Preučevan je bil učinek dodajanja giberilinske kisline $\left(\mathrm{GA}_{3}\right)$ kot obravnavanja pred cvetenjem na moškega starša 'Giza 178' $(R)$ in vpliv razmerja med moškimi $(R)$ in ženskimi rastlinami (A) (2R:10A, 2R:12A, 2R:14A in 2R:16A) za dve citoplazmatsko moško sterilni liniji (CMS), 'IR69625' in 'G46', na pridelek semena hibridnega riža. Raziskava je potrdila razlike $\mathrm{v}$ lastnostih navzkrižnega križanja in pridelku zrnja dveh CMS linij (IR69625A in G46A) pri uporabi štirih koncentracij $\mathrm{GA}_{3}$ uporabljenih dvakrat, pri 15-20\% in 35-40 \% latenju. CMS linije so bile na podploskvah, razmerje med moškimi (R) in ženskimi (A) rastlinami pa na njihovih podploskvah (2R:10A, 2R:12A, 2R:14A in 2R:16A). Rezultati so pokazali, da so se trajanje odpiranja cvetov ( $\mathrm{min})$, kot odprtega cveta $\left({ }^{0}\right)$, odstotek podaljšanih filamentov $(\%)$, dolžina filamentov $(\mathrm{mm})$, dolžina prašnic $(\mathrm{mm})$, višina rastlin $(\mathrm{cm})$ in število poganjkov na sadilno mesto pri moškem staršu 'Giza 178 ' značilno povečali pri uporabi $300 \mathrm{~g} \mathrm{GA}_{3} \mathrm{ha}^{-1}$.

Ključne besede: pridelovanje hibridnega riža; citoplazmatsko sterilne moške linije; giberilinska kislina $\left(\mathrm{GA}_{3}\right)$; razmerje moških in ženskih rastlin; latenje

1 Rice Research and Training Center, 33717, Sakha, Kafr Elsheikh, Field Crops Research Institute, Agricultural Research Center, Egypt

2 Agricultural Research Center, Field Crops Research Institute, Giza 12112, Egypt

3 Corresponding author, e-mail: adelrrtc.ghoneim@gmail.com 


\section{INTRODUCTION}

Hybrid rice breeding, which was initiated in Egypt has led to great improvement in rice production ( $\mathrm{Za}$ man et al., 2002; Hamad, 2018). Breeding high-yielding hybrid rice is one of the promising potential strategies in Egypt for increasing rice production. The hybrid rice technology exploits the phenomenon of heterosis or hybrid vigor. The heterosis can be defined as the superiority of F1 when two genetically dissimilar parents are crossed (Sindhua and Kumar, 2002). The three-line rice breeding system which uses cytoplasmic male sterile (CMS) lines (A), maintainer lines (B) and restorer lines $(\mathrm{R})$ has been proven to be the most useful genetic tool in producing $\mathrm{F} 1$ hybrid in rice.

The content of endogenous gibberellic acid $\left(\mathrm{GA}_{3}\right)$ in male $\mathrm{p}$ lines with pollen abortive wild rice cytoplasm (wild abortive [WA] type male sterile [MS] line) is generally lower than that of fertile plants, therefore, resulting in spikelets unavailable for cross-pollination and producing lower seed yield ( $\mathrm{Lu}, 1994$; Pan et al., 2013). Exogenous application of $\mathrm{GA}_{3}$ was done to cause the panicle base of the CMS line to emerge out of the leaf sheath (Gaballah, 2004; Gaballah et al., 2021). In addition, lower heading characteristics such as small spikelet openings, poor panicle layer carriage and poor stigma exsertion can severely reduce cross-pollination and limit seed yield production. Hence, hybrid rice seed production techniques should be improved to increase seed yields and reduce the cost of seeds (Virmani, 2002; Virmani et al., 2002).

Egypt is currently using a number of CMS lines for the hybrid rice-breeding programs. However, no information is available on how these CMS lines will respond to $\mathrm{GA}_{3}$ application with reference to their heading characteristics. Such data are very important to generate baseline information whether genotypic variations exist among CMS lines in response to $\mathrm{GA}_{3}$ pre-flowering treatment and whether such responses follow similar trends. This will also help in identifying CMS lines which are responsive to $\mathrm{GA}_{3}$ application to maximize their utilization in the development of new hybrid rice varieties with higher seed yield potential.

Therefore, the objective of this investigation was to study the performance of Giza178R male parents as affected by $\mathrm{GA}_{3}$ application rates and male to female ratio on the growth characteristics and hybrid seed yield production of two CMS lines (IR69625A and G46A).

\section{MATERIALS AND METHODS}

\subsection{EXPERIMENTAL SITE DESCRIPTION AND SOIL SAMPLES}

The field experiment was conducted during 2019 and 2020 rice growing seasons in Rice Research and Training Center (RRTC) experimental farm, Sakha, Kafr El-Sheikh, Egypt. Representative soil sample was taken from 0-20 cm depth before the growing season. The soil samples were air-dried, ground and passed through $2 \mathrm{~mm}$ sieve. Composite soil samples were taken and analyzed for physical and chemical characteristics of the soil namely, electrical conductivity (EC,) $\mathrm{pH}$, organic matter (OM), texture, cations and anions following the standard methods as described by (Page et al., 1982). The physico-chemical characteristics of the soil are presented in Table (1).

\subsection{EXPERIMENTAL LAYOUT}

The experiment was set up as split split-plot design with three replications. The main plots were devoted to two CMS lines (IR69625A and G46A) for male parent male parent. The $\mathrm{GA}_{3}$ application rates $(0,150,200$ and $300 \mathrm{~g} \mathrm{GA}_{3} \mathrm{ha}^{-1}$ ) for male parent Giza 178R was allocated to subplots and male to female ratio $(2 \mathrm{R}: 10 \mathrm{~A}, 2 \mathrm{R}: 12 \mathrm{~A}$, $2 \mathrm{R}: 14 \mathrm{~A}$ and $2 \mathrm{R}: 16 \mathrm{~A}$ ) between male (R) to female (A) was arranged in the sub-sub plots.

\subsection{PLANT MATERIALS}

They were obtained from international rice research institute (IRRI) and China and contain the wild rice with abortive pollen CMS (Table 2).

\subsection{CULTURAL PRACTICES}

Phosphorus fertilizer was applied @ $36 \mathrm{~kg} \mathrm{P}_{2} \mathrm{O}_{5}$ $\mathrm{ha}^{-1}$ as superphosphate $\left(15.5 \% \mathrm{P}_{2} \mathrm{O}_{5}\right)$ as soil basal application. Nitrogen fertilizer was applied @ $165 \mathrm{~kg} \mathrm{ha}^{-1}$ as urea. Two thirds of the recommended $\mathrm{N}$ fertilizer were added as soil basal application, and the other one third was applied at panicle initiation. Zinc sulphate at the rate of $50 \mathrm{~kg} \mathrm{ha}^{-1}$ was added during soil preparation.

Rice seeds @ $15 \mathrm{~kg}$ of the CMS Lines (IR69625A and $\mathrm{G} 46 \mathrm{~A}$ ) and $5 \mathrm{~kg}$ for the male parent (Giza $178 \mathrm{R}$ ) were soaked in fresh water for 24 hours, then incubated for 48 hours to hasten early germination. To get a proper synchronization of flowering, the CMS line IR69625A (as female parent) was sown on May ${ }^{1 \text { st }}$ which is six 
Table 1: The physical and chemical characteristics of the soil during 2019 and 2020 growing seasons

\begin{tabular}{|c|c|c|c|c|c|c|c|c|}
\hline Season & $\mathrm{pH}$ & $\begin{array}{l}\mathrm{EC} \\
\left(\mathrm{dS} \mathrm{m}^{-1}\right)\end{array}$ & $\begin{array}{l}\text { NPK } \\
\left(\mathrm{mg} \mathrm{kg}^{-1}\right)\end{array}$ & & $\begin{array}{l}\text { Clay } \\
(\%)\end{array}$ & $\begin{array}{l}\text { Silt } \\
(\%)\end{array}$ & $\begin{array}{l}\text { Sand } \\
(\%)\end{array}$ & $\begin{array}{l}\text { OM } \\
(\%)\end{array}$ \\
\hline 2019 & 7.84 & 1.50 & $339 \quad 13.7$ & 329 & 56.4 & 28.3 & 15.3 & 1.35 \\
\hline 2020 & 7.89 & 1.59 & $368 \quad 14.7$ & 359 & 58.6 & 27.1 & 14.3 & 1.40 \\
\hline
\end{tabular}

EC; Electrical conductivity, OM; Organic matter

Table 2: Cytoplasmic male sterile (CMS) lines used for evaluation

\begin{tabular}{lll}
\hline CMS Lines & Cytoplasmic source & Origin \\
\hline IR 69625A & Wild abortive (WA) CMS line & IRRI \\
G46A & Gambiaca CMS line & China \\
\hline
\end{tabular}

days earlier than the male parent 'Giza 178 R' while, the CMS line G46A (as female parent) was sown on 16 May. Thirty days old seedlings (3-4) per hill of $\mathrm{R}$ and A lines were transplanted by 3-4 and 2 seedlings per hill, respectively). Row direction was perpendicular to wind direction. The row spacing maintained for $\mathrm{R}-\mathrm{R}, \mathrm{R}-\mathrm{A}$ and A-A lines were 20,30, and $15 \mathrm{~cm}$, respectively. Hill spacing for both $\mathrm{R}$ and $\mathrm{A}$ lines was maintained at 15 $\mathrm{cm}$. Isolation space of $100 \mathrm{~m}$ was considered for CMS seed production. Moreover, the experimental field was surrounded by an additional 20 rows of $\mathrm{R}$ line to avoid any possibility of cross pollination. Every main plot was isolated by plastic barrier ( $2.5 \mathrm{~m}$ height) to avoid any pollen grain movement from treatment to another.

\subsection{GIBBERELLIC ACID PREPARATION AND AP- PLICATION}

Gibberellic Acid ( $\mathrm{GA}_{3}$ ) powder with $90.7 \%$ purity was used. Since $\mathrm{GA}_{3}$ cannot be completely dissolved in distilled water. In $100 \mathrm{ml}$ of ethanol alcohol (70\%), was used to dissolve the $\mathrm{GA}_{3}$ powder before it was mixed with water. Application of $\mathrm{GA}_{3}$ was done in two splits. The first split consisted of $40 \%$ of the total amount of $\mathrm{GA}_{3}$ applied at 15-20\% heading. The second split in which the remaining $60 \%$ of the total amount of $\mathrm{GA}_{3}$ was applied at 35-40\% heading. Supplementary pollination was done by shaking the pollen parent ( $\mathrm{R}$ line) with bamboo sticks. This operation was done 3-4 times between 9.30 am to 12.30 am for a period of 10 days.

\subsection{TRAIT EVALUATION}

At complete heading, duration of floret opening (min), angle of floret opening $\left({ }^{0}\right)$, filaments exertion
(\%), filaments length (mm) and anther length (mm) of male parent 'Giza 178' were recorded. Ten panicles of male parent 'Giza 178' from each plot were randomly collected to estimate the panicle length $(\mathrm{cm})$. Also, five hills of male parent 'Giza 178' were randomly identified from each plot to estimate the plant height $(\mathrm{cm})$ and number of tillers hill ${ }^{-1}$. Data was collected for CMS lines where it was days to heading $50 \%$, plant height $(\mathrm{cm})$, panicle exsertion (\%), flag leaf angle $\left({ }^{0}\right)$, 1000-grain mass $(\mathrm{g})$, panicle length $(\mathrm{cm})$, number of fertile panicles hill $^{-1}$, panicle mass $(\mathrm{g})$, seed set $(\%)$, seed yield ( $\left.\mathrm{t} \mathrm{ha} \mathrm{a}^{-1}\right)$, and harvest index (\%). After harvesting, rice grain yield was estimated in each plot, and grain yield was adjusted to $14 \%$ moisture content and converted to tons ha ${ }^{-1}$.

Panicle exsertion \% was estimated according to the following equation:

Panicle exsertion \% $=\frac{\text { Exserted panicle length }(\mathrm{cm})}{\text { Panicle length }(\mathrm{cm})} \times 100$

Seed set \% was calculated according to the following equation:

Seed set $\%=\frac{\text { Number of filled grains } / \text { panicle }}{\text { Total Spikelet number } / \text { panicle }} \times 100$

\subsection{STATISTICAL ANALYSIS}

All data collected were subjected to standard statistical analysis of variance following the method described by Gomez and Gomez (1984). Different means were compared by Duncan's multiple range test (DMRT) with a $5 \%$ probability level.

\section{RESULTS AND DISCUSSION}

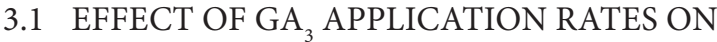 GROWTH TRAITS OF MALE PARENT}

The effect of different $\mathrm{GA}_{3}$ application rates on male parent traits such as duration of floret opening, angle of floret opening, filaments exertion, filaments length, an- 
ther length, plant height, number of tiller hill ${ }^{-1}$ and panicle length, are presented in (Table 3). The results indicated that, $\mathrm{GA}_{3}$ applied for male parent up to $300 \mathrm{~g} \mathrm{GA}_{3}$ $\mathrm{ha}^{-1}$ recorded a significant increase in duration of floret opening, angle of floret opening, filaments exertion, filaments length, anther length, plant height, number of tiller hill-1 and panicle length as compared with $\mathrm{GA}_{3} 0$ $\mathrm{g} \mathrm{ha}^{-1}$ treatment in both seasons. Application of $300 \mathrm{~g}$ $\mathrm{GA}_{3} \mathrm{ha}^{-1}$ on male parent gave the highest duration of floret opening (130.59 and $129.94 \mathrm{~min}$ ), the maximum angle of floret opening (41.96 and $\left.44.30^{\circ}\right)$, the highest values of filaments exertion (80.81 and $90.15 \%$ ), filaments length ( 9.34 and $9.78 \mathrm{~mm}$ ), anther length (3.35 and $3.55 \mathrm{~mm}$ ), the tallest plant (126.49 and $127.36 \mathrm{~cm})$, the highest number of tiller hill-1 ${ }^{-1} 24.83$ and 25.19) and longest panicle (25.71 and 25.90), during 2019 and 2020 seasons, respectively. A significant increase in panicle exsertion was observed on $\mathrm{GA}_{3}$ application. The highest value of panicle exsertion was observed at the rate of $300 \mathrm{~g} \mathrm{GA}_{3} \mathrm{ha}^{-1}$, regardless of CMS lines used, indicating that CMS lines were sensitive to exogenous $\mathrm{GA}_{3}$ application, hence, the problem of the leaf sheath enclosing the panicle could be alleviated by $\mathrm{GA}_{3}$ application. Panicle exsertion influenced the percentage of exposed spikelets available for pollination, as higher panicle exsertion means a greater number of exposed spikelets. It also tended to scatter the panicle branches providing more space for each spikelet to trap airborne pollen. The increase in panicle exsertion was mainly a function of the elongating topmost internode in response to $\mathrm{GA}_{3}$ application that consequently pushes the panicle out of the flag leaf sheath. Therefore, poor panicle exsertion of CMS lines was due to the inability of the topmost internodes to elongate during heading stage. The lowest values of above-mentioned traits were obtained with $\mathrm{GA}_{3}$ $0 \mathrm{~g} \mathrm{ha}^{-1}$ application rate (Table 3). The improved floral traits of male parent were due to increased activity of cell division, enlargement and elongation. Gibberellins are plant hormones that regulate various processes of plant growth and development, which are particularly important in cell elongation (Hedden and Phillips, 2000).

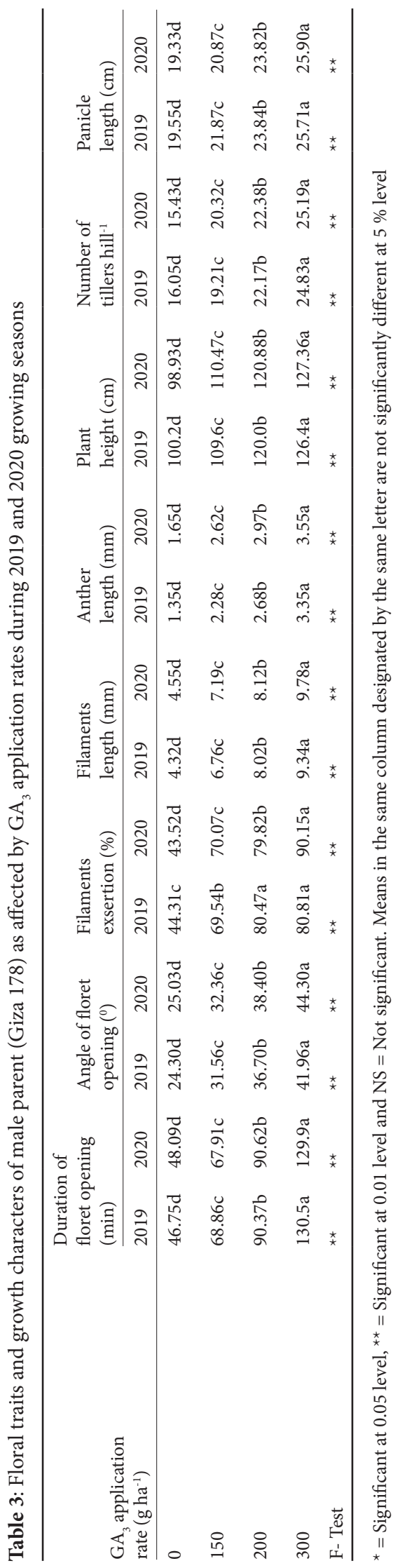




\section{$3.2 \mathrm{~F}_{1}$ SEEDS OF CMS LINES CHARACTERISTIC AS AFFECTED BY GA ${ }_{3}$ APPLICATION FOR MALE PARENT AND MALE TO FEMALE RA- TIO}

Days to $50 \%$ heading, plant height, panicle exsertion, flag leaf angle, panicle length and 1000-grain mass were not significantly affected by $\mathrm{GA}_{3}$ application rates for male parent and male to female ratio (Table 4). The results showed that there were significant differences between the two CMS lines IR69625A and G46A. Where CMS line IR69625A gave the longest duration to $50 \%$ heading, produced the tallest plants, the longest panicle exsertion, the highest panicle length and the increased flag leaf angle during both seasons. On the other hand, the CMS line G46A recorded the highest 1000 -grain mass during the both seasons. The variation between the CMS lines could be attributed to the difference in genetic background. The results are in agreement with those reported by (Hamad et al., 2015). They founded that, the different doses of $\mathrm{GA}_{3}$ showed highly significantly influence on panicle length and panicle exsertion when 2:4 row ratio. Similar results agreement with those were reported by Ehsan and Robert (2019). Results in Table (4) also showed that, the all of interactions were not significantly affected on days to $50 \%$ heading, plant height, panicle exsertion, panicle length, flag leaf angle and 1000-grain mass in both growing seasons.

Number of fertile panicles hill-1 ${ }^{-1}$, panicle mass, seed set $\%$, seed yield and harvest index \% of two CMS lines as affected by doses of $\mathrm{GA}_{3}$ application rates for male parent and male to female ratio as well as their interactions are shown in (Table 5). The results indicated that, the CMS line IR 69625A recorded the highest values of number of fertile panicles hill ${ }^{-1}$, panicle mass, seed set $\%$, seed yield and harvest index \% in both seasons. On the other hand, the CMS line G46A recorded the lowest values of number of fertile panicles hill- ${ }^{-1}$, panicle mass, seed set, seed yield and harvest index \% in both seasons (Table 5). The variation between the CMS lines could be attributed to the difference in genetic background. The results are in agreement with those reported by Gaballah, (2004). Results in Table (5) also showed that application $\mathrm{GA}_{3}$ on the male parent had a high significant effect on the number of fertile panicles hill-1 ${ }^{-1}$ panicle mass, seed set, seed yield and harvest index \%. The dose of $\mathrm{GA}_{3}$ application at $300 \mathrm{~g} \mathrm{ha}^{-1}$ for male parent recorded the highest values of number of fertile panicle hill $^{-1}$, panicle mass, seed set, seed yield and harvest index \% 2019 and 2020 seasons, while the lowest values recoded by control $\left(\mathrm{GA}_{3} 0 \mathrm{~g} \mathrm{ha}^{-1}\right)$ in both seasons. The increase in plant height is due to increased activity of cell division, enlargement and elongation. Gibberellins are plant hormones that regulate various processes of plant growth and development, which are particularly important in stem elongation which enhances the cross pollination between both parents. The results are in agreement with those reported by (Hedden and Phillips, 2000; Sakamoto et al., 2004; Sun, 2004; Tiwari et al., 2011). Male to female ratio significantly influenced number of fertile panicle hill ${ }^{-1}$, panicle mass, seed set, seed yield and harvest index $\%$. The male to female ratio $2 \mathrm{R}: 14 \mathrm{~A}$ recorded the highest values number of fertile panicles hill ${ }^{-1}$, panicle mass, seed set, seed yield and harvest index\% during both seasons. This might be due to that the application of $\mathrm{GA}_{3}$ for male parent led to a noticeable improvement in the characteristics) plant height, panicle exsertion, flag leaf angle, panicle length) of the male parent, which made it able to pollinate the highest number of male lines consequently, increase the number of fertile panicle hill ${ }^{-1}$ and seed yield. On the other hand, the male to female ratio $2 \mathrm{R}: 10 \mathrm{~A}$ recorded the lowest values of number of fertile panicles hill ${ }^{-1}$, panicle mass, seed set, seed yield and harvest index \% during the both seasons.

\subsection{INTERACTION EFFECT}

All types of interactions among CMS lines, doses of $\mathrm{GA}_{3}$ application rates for male parent and male to female ratio had highly significant effect on number of fertile panicles hill ${ }^{-1}$, panicle mass, seed set, seed yield and harvest index during 2019 and 2020 seasons (Table 5).

The results in Table (6) indicated that, the interaction between the CMS lines and $\mathrm{GA}_{3}$ different application rates for male parent were highly significantly affected on number of fertile panicles hill ${ }^{-1}$, panicle mass, seed set, seed yield and harvest index \% in both seasons. The CMS line IR69625A, with dose of $\mathrm{GA}_{3}$ at the rate of $300 \mathrm{~g} \mathrm{ha}^{-1}$ for male parent recorded the highest values of number of fertile panicles hill ${ }^{-1}$, panicle mass, seed set, seed yield and harvest index $\%$ in both seasons. On the contrary, the CMS line G46A with $0 \mathrm{~g} \mathrm{GA}_{3}$ ha $^{-1}$ application rates for male parent recoded the lowest values of number of fertile panicles hill ${ }^{-1}$, panicle mass, seed set, seed yield and harvest index \% in 2019 and 2020 seasons. The results are in agreement with those reported by Sirajul et al. (2005); Gavino et al. (2008). 


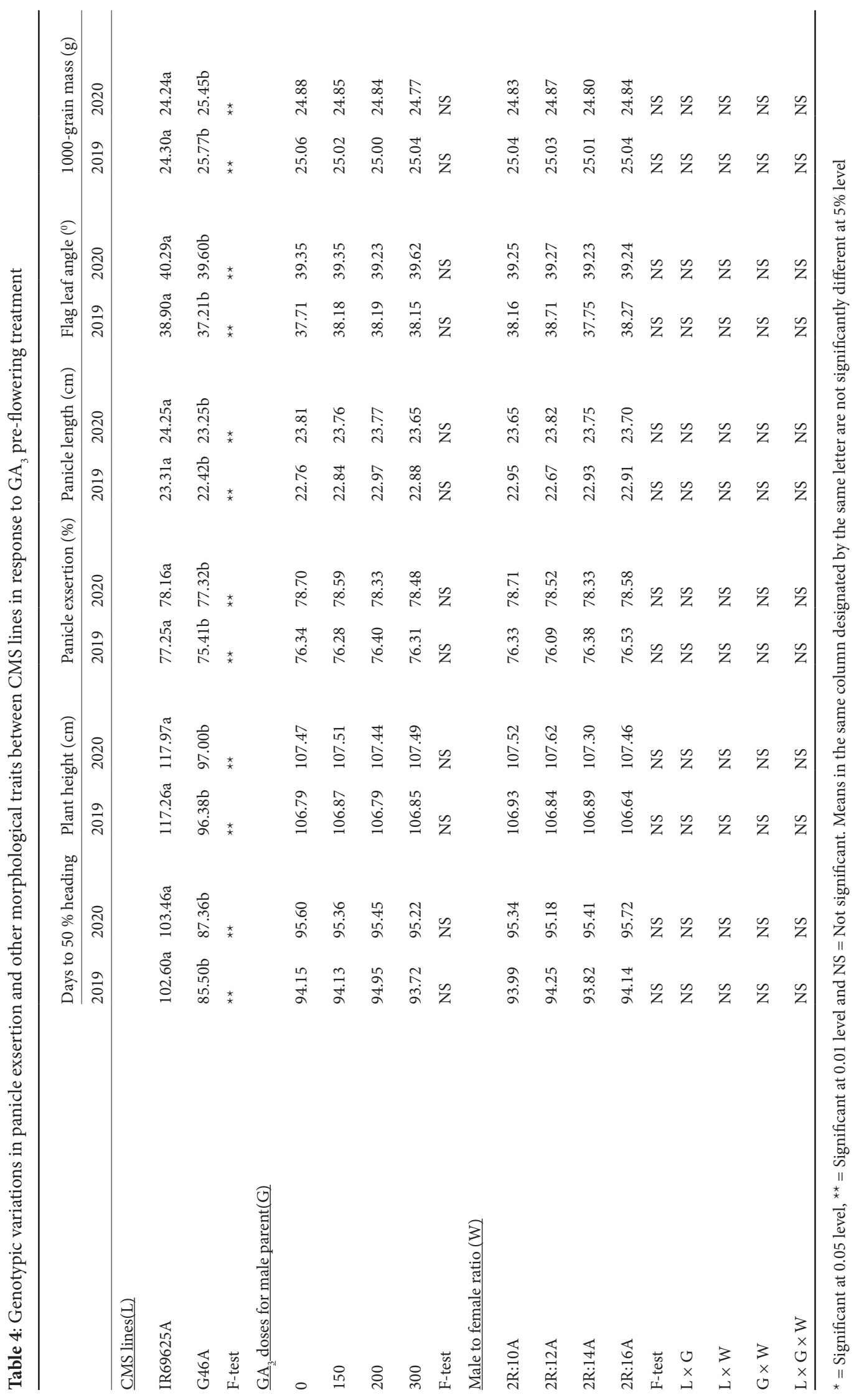

6 Acta agriculturae Slovenica, 117/3 - 2021 


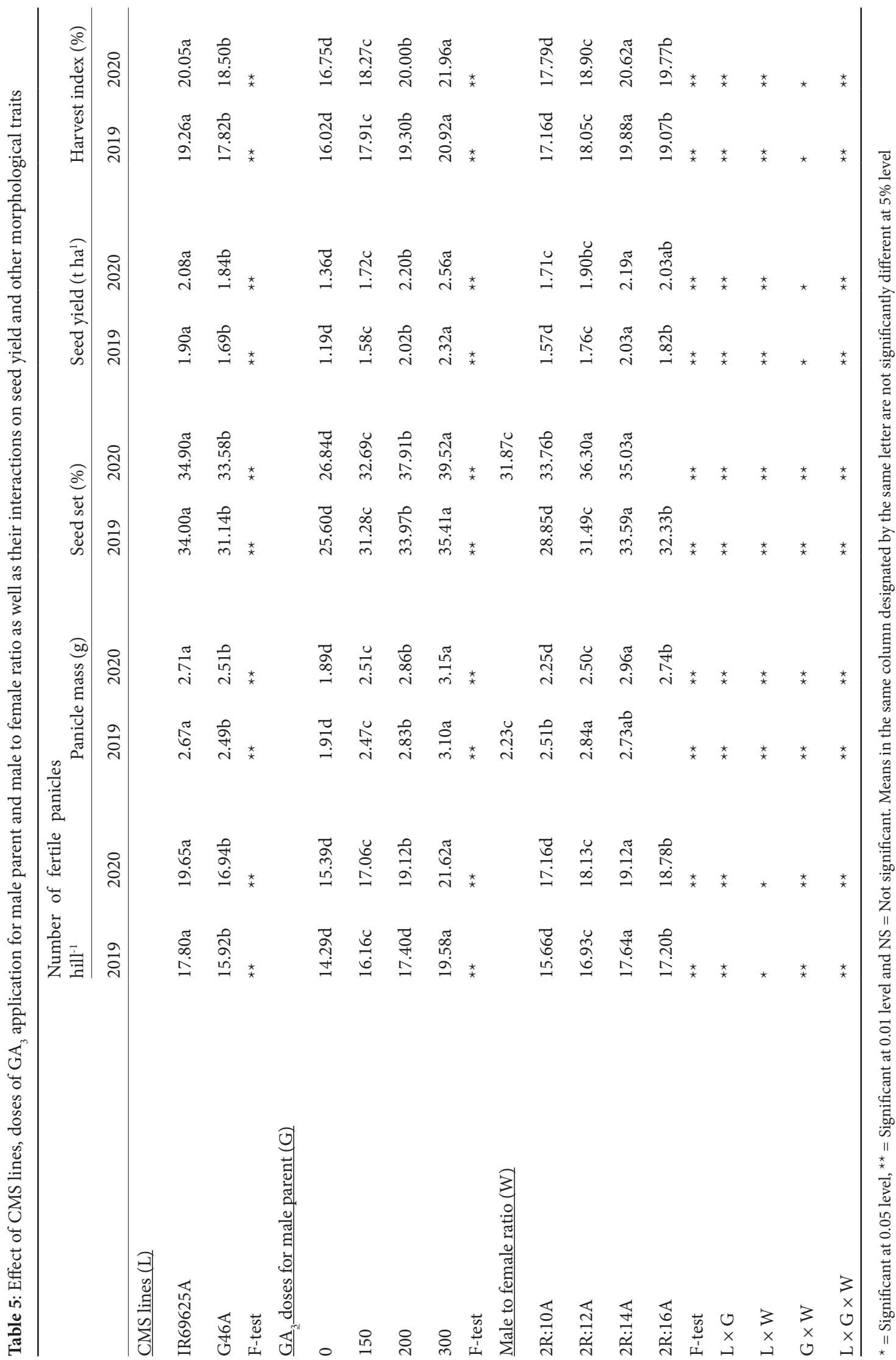


Table 6: Effect of interaction between CMS liens and doses of $\mathrm{GA}_{3}$ application for male parent on panicle characteristics and yield during 2019 and 2020 seasons

\begin{tabular}{|c|c|c|c|c|c|c|c|c|c|c|c|}
\hline \multirow{2}{*}{$\begin{array}{l}\text { CMS } \\
\text { Lines } \\
(\mathrm{L})\end{array}$} & \multirow{2}{*}{$\begin{array}{l}\mathrm{GA}_{3} \text { doses for } \\
\text { male parent }(\mathrm{G})\end{array}$} & \multicolumn{2}{|c|}{$\begin{array}{l}\text { Number of fertile } \\
\text { panicles hill }^{-1}\end{array}$} & \multicolumn{2}{|c|}{ Panicle mass (g) } & \multicolumn{2}{|c|}{ Seed Set (\%) } & \multicolumn{2}{|c|}{$\begin{array}{l}\text { Seed } \\
\text { yield }\left(\mathrm{t} \mathrm{ha}^{-1}\right)\end{array}$} & \multicolumn{2}{|c|}{$\begin{array}{l}\text { Harvest } \\
\text { Index (\%) }\end{array}$} \\
\hline & & 2019 & 2020 & 2019 & 2020 & 2019 & 2020 & 2019 & 2020 & 2019 & 2020 \\
\hline \multirow[t]{4}{*}{ IR6962A } & 0 & $15.50 \mathrm{~d}$ & $16.21 \mathrm{~d}$ & $1.95 \mathrm{~d}$ & $1.92 \mathrm{~d}$ & $25.69 f$ & $27.19 f$ & $1.35 \mathrm{e}$ & $1.48 \mathrm{de}$ & $16.48 \mathrm{e}$ & $17.23 \mathrm{de}$ \\
\hline & 150 & $16.75 c$ & $18.14 \mathrm{c}$ & $2.50 \mathrm{c}$ & $2.62 b c$ & $31.93 \mathrm{~d}$ & $33.4 \mathrm{~d}$ & $1.72 \mathrm{~d}$ & $1.85 \mathrm{c}$ & $18.43 \mathrm{c}$ & $19.21 \mathrm{c}$ \\
\hline & 200 & $18.36 \mathrm{~b}$ & $20.5 b$ & $2.90 \mathrm{ab}$ & $3.03 \mathrm{ab}$ & $34.5 \mathrm{bc}$ & $38.7 \mathrm{~b}$ & $2.10 \mathrm{bc}$ & $2.27 \mathrm{~b}$ & $20.03 b$ & $20.68 b$ \\
\hline & 300 & $20.55 a$ & $23.71 \mathrm{a}$ & $3.22 \mathrm{a}$ & $3.27 \mathrm{a}$ & $35.82 \mathrm{a}$ & $40.2 \mathrm{a}$ & $2.43 \mathrm{a}$ & $2.71 \mathrm{a}$ & $22.11 \mathrm{a}$ & $22.99 a$ \\
\hline \multirow[t]{4}{*}{ G46A } & 0 & $13.07 f$ & $14.57 \mathrm{e}$ & $1.87 \mathrm{~d}$ & $1.87 \mathrm{~d}$ & $25.51 \mathrm{f}$ & $26.49 \mathrm{i}$ & $1.14 \mathrm{f}$ & $1.24 \mathrm{e}$ & $15.57 \mathrm{e}$ & $16.18 \mathrm{e}$ \\
\hline & 150 & $15.57 \mathrm{~d}$ & $15.98 \mathrm{~d}$ & $2.42 \mathrm{c}$ & $2.46 \mathrm{c}$ & $30.64 \mathrm{e}$ & $31.9 \mathrm{e}$ & $1.45 \mathrm{e}$ & $1.58 \mathrm{~d}$ & $17.40 \mathrm{~d}$ & $17.54 \mathrm{~d}$ \\
\hline & 200 & 16. $4 \mathrm{c}$ & $17.67 \mathrm{c}$ & $2.76 \mathrm{~b}$ & $2.70 \mathrm{bc}$ & $33.40 \mathrm{c}$ & $37.0 \mathrm{c}$ & $1.97 \mathrm{c}$ & $2.12 \mathrm{bc}$ & $18.58 \mathrm{c}$ & $19.23 c$ \\
\hline & 300 & $18.61 \mathrm{~b}$ & $19.54 b$ & $2.88 \mathrm{ab}$ & $3.03 \mathrm{ab}$ & $34.9 \mathrm{ab}$ & $38.8 \mathrm{~b}$ & $2.21 \mathrm{~b}$ & $2.41 \mathrm{~b}$ & $19.73 b$ & $20.94 b$ \\
\hline
\end{tabular}

Means in the same column designated by the same letter are not significantly different at $5 \%$ level

The results in Table (7) showed that the interaction between CMS lines and male to female ratio were significantly affected number of fertile panicles hill ${ }^{1}$, panicle mass, seed set, seed yield and harvest index $\%$ in both seasons. The male to female ratio of $2 \mathrm{R}: 14 \mathrm{~A}$ with CMS line IR69625A, recorded the highest values of number of fertile panicles hill ${ }^{-1}$, panicle mass, seed set $\%$, seed yield and harvest index $\%$ in both seasons. This may be due to the optimum availability of pollen that led to the highest effective grain formation. On the other hand, the lowest values of number of fertile pani- cles hill ${ }^{-1}$, panicle mass, seed set $\%$, seed yield and harvest index \% were obtained by CMS line G46A when male to female ratio of 2R:10A during 2019 and 2020 seasons. The results are in agreement with those reported by Abo-Youssef (2009).

The results in Table (8) showed that the interaction between doses of $\mathrm{GA}_{3}$ application for male parent and male to female ratio was significantly affected number of fertile panicles hill ${ }^{-1}$, panicle mass, seed set $\%$, seed yield and harvest index (\%) in both seasons. The male to female ratio $2 \mathrm{R}: 14 \mathrm{~A}$ with applied $300 \mathrm{~g} \mathrm{GA}_{3} \mathrm{ha}^{-1}$ re-

Table 7: Effect of interaction between CMS lines and male to female ratio on panicle characteristics and yield during 2019 and 2020 seasons

\begin{tabular}{|c|c|c|c|c|c|c|c|c|c|c|c|}
\hline \multirow[b]{2}{*}{ CMS Lines } & \multirow{2}{*}{$\begin{array}{l}\text { Male to Fe- } \\
\text { male ratio }\end{array}$} & \multicolumn{2}{|c|}{$\begin{array}{l}\text { Number of fertile } \\
\text { panicles hill- }\end{array}$} & \multicolumn{2}{|c|}{ Panicle mass (g) } & \multicolumn{2}{|l|}{$\begin{array}{l}\text { Seed } \\
\text { Set }(\%)\end{array}$} & \multicolumn{2}{|c|}{$\begin{array}{l}\text { Seed } \\
\text { yield }\left(\mathrm{t} \mathrm{ha}^{-1}\right)\end{array}$} & \multicolumn{2}{|c|}{$\begin{array}{l}\text { Harvest } \\
\text { Index (\%) }\end{array}$} \\
\hline & & 2019 & 2020 & 2019 & 2020 & 2019 & 2020 & 2019 & 2020 & 2019 & 2020 \\
\hline \multirow[t]{4}{*}{ IR69625A } & 2R:10A & $16.84 \mathrm{c}$ & $18.18 \mathrm{c}$ & $2.31 \mathrm{~d}$ & $2.30 \mathrm{~d}$ & $29.17 d$ & $32.3 \mathrm{~cd}$ & $1.71 \mathrm{~cd}$ & $1.84 \mathrm{c}$ & 18.0de & $18.84 \mathrm{c}$ \\
\hline & 2R:12A & $17.79 \mathrm{~b}$ & $19.70 \mathrm{~b}$ & $2.61 b c$ & $2.59 b c$ & $31.81 \mathrm{~b}$ & $34.23 b$ & $1.85 \mathrm{bc}$ & $2.03 b$ & $18.8 \mathrm{~cd}$ & $19.67 b$ \\
\hline & 2R:14A & $18.60 \mathrm{a}$ & $20.62 \mathrm{a}$ & $2.93 \mathrm{a}$ & $3.11 \mathrm{a}$ & $34.17 \mathrm{a}$ & $37.29 \mathrm{a}$ & $2.15 \mathrm{a}$ & $2.32 \mathrm{a}$ & $20.57 \mathrm{a}$ & $21.33 a$ \\
\hline & 2R:16A & $17.92 b$ & $20.12 \mathrm{a}$ & $2.8 \mathrm{ab}$ & $2.84 \mathrm{ab}$ & $32.8 \mathrm{ab}$ & $35.69 \mathrm{~b}$ & $1.88 \mathrm{bc}$ & $2.12 \mathrm{ab}$ & $19.59 b$ & $20.3 \mathrm{ab}$ \\
\hline \multirow[t]{4}{*}{ G46A } & 2R:10A & $14.47 \mathrm{e}$ & $16.14 \mathrm{e}$ & $2.16 \mathrm{~d}$ & $2.20 \mathrm{~d}$ & $28.54 \mathrm{~d}$ & $31.38 \mathrm{~d}$ & $1.42 \mathrm{e}$ & $1.59 \mathrm{~d}$ & $16.29 \mathrm{f}$ & $16.74 d$ \\
\hline & 2R:12A & $16.07 \mathrm{~d}$ & $16.5 \mathrm{~cd}$ & $2.41 \mathrm{~cd}$ & $2.41 \mathrm{~cd}$ & $31.17 \mathrm{c}$ & $33.29 \mathrm{c}$ & $1.66 \mathrm{~d}$ & $1.76 \mathrm{~cd}$ & $17.26 \mathrm{e}$ & $18.14 \mathrm{c}$ \\
\hline & 2R:14A & $16.6 \mathrm{~cd}$ & $17.6 \mathrm{~cd}$ & $2.75 \mathrm{ab}$ & $2.80 \mathrm{ab}$ & $33.02 \mathrm{a}$ & $35.3 b$ & $1.92 \mathrm{~b}$ & $2.07 \mathrm{ab}$ & $19.1 b c$ & $19.92 b$ \\
\hline & 2R:16A & $16.4 \mathrm{~cd}$ & $17.4 \mathrm{~d}$ & $2.64 \mathrm{~b}$ & $2.64 b c$ & $31.8 \mathrm{bc}$ & $34.36 \mathrm{~b}$ & $1.77 \mathrm{~cd}$ & $1.9 \mathrm{bc}$ & $18.55 c$ & $19.1 \mathrm{bc}$ \\
\hline
\end{tabular}

Means in the same column designated by the same letter are not significantly different at $5 \%$ level 
Table 8: Effect of interaction between doses of $\mathrm{GA}_{3}$ application for male parent and male to female row ratio on panicle characteristics and yield during 2019 and 2020 seasons

\begin{tabular}{|c|c|c|c|c|c|c|c|c|c|c|}
\hline \multirow{2}{*}{$\begin{array}{l}\mathrm{GA}_{3} \text { doses for male } \\
\text { parent } \\
\left(\mathrm{g} \mathrm{ha}^{-1)}\right.\end{array}$} & \multirow{2}{*}{$\begin{array}{l}\text { Male to } \\
\text { female } \\
\text { ratio }\end{array}$} & \multicolumn{2}{|c|}{$\begin{array}{l}\text { Number of fertile } \\
\text { panicles hill- }\end{array}$} & \multicolumn{2}{|c|}{$\begin{array}{l}\text { Panicle } \\
\text { mass (g) }\end{array}$} & $\begin{array}{l}\text { Seed } \\
\text { set }(\%)\end{array}$ & \multicolumn{2}{|c|}{$\begin{array}{l}\text { Seed yield } \\
\left(\mathrm{t} \mathrm{ha}^{-1}\right)\end{array}$} & \multicolumn{2}{|c|}{$\begin{array}{l}\text { Harvest } \\
\text { Index (\%) }\end{array}$} \\
\hline & & 2019 & 2020 & 2019 & 2020 & $2019 \quad 2020$ & 2019 & 2020 & 2019 & 2020 \\
\hline \multirow[t]{4}{*}{0} & 2R:10A & $14.15 f$ & $14.61 \mathrm{~h}$ & $1.84 \mathrm{~d}$ & $1.78 \mathrm{e}$ & $25.50 \mathrm{e} 26.57 \mathrm{~d}$ & $1.20 \mathrm{~g}$ & $1.28 \mathrm{~g}$ & $15.59 \mathrm{~g}$ & $16.51 \mathrm{f}$ \\
\hline & 2R:12A & $14.53 \mathrm{f}$ & $15.29 \mathrm{gh}$ & $1.92 \mathrm{~d}$ & $1.88 \mathrm{e}$ & $25.46 \mathrm{e} 26.92 \mathrm{~d}$ & $1.29 \mathrm{fg}$ & $1.37 \mathrm{f}$ & $16.0 \mathrm{fg}$ & $16.66 f$ \\
\hline & 2R:14A & $14.25 f$ & $15.92 \mathrm{~g}$ & $1.94 \mathrm{~d}$ & $1.99 \mathrm{e}$ & 25.7de $27.11 \mathrm{~d}$ & $1.25 \mathrm{fg}$ & $1.46 \mathrm{f}$ & $16.2 \mathrm{fg}$ & $17.14 \mathrm{ef}$ \\
\hline & 2R:16A & $14.22 \mathrm{f}$ & $15.74 \mathrm{~g}$ & $1.94 \mathrm{~d}$ & $1.91 \mathrm{e}$ & 25.6de $26.75 d$ & $1.24 \mathrm{~g}$ & $1.34 \mathrm{f}$ & $16.2 \mathrm{fg}$ & $16.72 \mathrm{f}$ \\
\hline \multirow[t]{4}{*}{150} & 2R:10A & $15.57 \mathrm{e}$ & $16.00 \mathrm{~g}$ & $1.93 \mathrm{~d}$ & $1.98 \mathrm{e}$ & $28.28 \mathrm{~d} 28.68 \mathrm{~d}$ & $1.39 \mathrm{fg}$ & $1.48 \mathrm{f}$ & $16.6 f g$ & $16.67 f$ \\
\hline & 2R:12A & $16.17 \mathrm{de}$ & $16.67 \mathrm{f}$ & $2.27 \mathrm{c}$ & $2.35 \mathrm{~d}$ & $31.26 \mathrm{c} 32.01 \mathrm{c}$ & $1.55 \mathrm{ef}$ & $1.57 \mathrm{f}$ & $17.51 \mathrm{e}$ & $18.19 \mathrm{e}$ \\
\hline & 2R:14A & $16.60 \mathrm{~d}$ & $17.91 \mathrm{e}$ & $2.92 \mathrm{~b}$ & $3.00 \mathrm{c}$ & $33.60 \mathrm{~b} 36.10 \mathrm{~b}$ & $1.78 \mathrm{de}$ & $1.99 \mathrm{~d}$ & $19.04 \mathrm{c}$ & $19.67 d$ \\
\hline & 2R:16A & 16.30de & $17.67 \mathrm{e}$ & $2.76 \mathrm{~b}$ & $2.86 \mathrm{c}$ & $32.00 \mathrm{c} 33.99 \mathrm{c}$ & $1.59 \mathrm{de}$ & $1.82 \mathrm{e}$ & $18.45 \mathrm{e}$ & $18.98 \mathrm{~d}$ \\
\hline \multirow[t]{4}{*}{200} & 2R:10A & $16.01 \mathrm{de}$ & $17.62 \mathrm{ef}$ & $2.48 \mathrm{c}$ & $2.48 \mathrm{~d}$ & $29.6 c d 34.45 c$ & $1.70 \mathrm{de}$ & $1.86 \mathrm{~d}$ & $17.45 \mathrm{e}$ & $18.10 \mathrm{e}$ \\
\hline & 2R:12A & $17.27 \mathrm{c}$ & $19.30 \mathrm{~d}$ & $2.79 \mathrm{~b}$ & $2.74 \mathrm{~cd}$ & $34.31 \mathrm{~b} 37.50 \mathrm{~b}$ & $1.95 c$ & $2.09 \mathrm{c}$ & $18.62 \mathrm{e}$ & $19.61 d$ \\
\hline & 2R:14A & $18.48 b$ & $20.00 \mathrm{~cd}$ & $3.11 \mathrm{a}$ & $3.36 \mathrm{ab}$ & $37.00 \mathrm{a} 40.40 \mathrm{a}$ & $2.33 \mathrm{~b}$ & $2.50 \mathrm{~b}$ & $21.0 \mathrm{bc}$ & $21.71 \mathrm{~b}$ \\
\hline & 2R:16A & $17.85 c$ & $19.56 \mathrm{~d}$ & $2.94 \mathrm{~b}$ & $2.88 \mathrm{c}$ & $34.97 \mathrm{~b} 39.2 \mathrm{ab}$ & $2.15 c$ & $2.34 \mathrm{bc}$ & $20.07 c$ & $20.59 c d$ \\
\hline \multirow[t]{4}{*}{300} & 2R:10A & $16.90 \mathrm{~d}$ & $20.43 \mathrm{~cd}$ & $2.69 \mathrm{~b}$ & $2.77 \mathrm{c}$ & $32.03 \mathrm{c} 37.81 \mathrm{~b}$ & $1.92 \mathrm{c}$ & $2.25 \mathrm{c}$ & 18.9de & $19.90 d$ \\
\hline & 2R:12A & $19.77 b$ & $21.27 \mathrm{bc}$ & $3.07 \mathrm{ab}$ & $3.03 b c$ & $34.94 \mathrm{~b} 38.6 \mathrm{ab}$ & $2.20 \mathrm{~b}$ & $2.57 \mathrm{ab}$ & $20.0 \mathrm{~cd}$ & $21.17 \mathrm{c}$ \\
\hline & 2R:14A & $21.23 \mathrm{a}$ & $22.65 a$ & $3.39 \mathrm{a}$ & $3.49 \mathrm{a}$ & $38.00 \mathrm{a} 41.59 \mathrm{a}$ & $2.78 \mathrm{a}$ & $2.83 \mathrm{a}$ & $23.16 \mathrm{a}$ & $23.99 a$ \\
\hline & 2R:16A & $20.43 a$ & $22.1 \mathrm{ab}$ & $3.27 \mathrm{a}$ & $3.31 \mathrm{ab}$ & $36.67 \mathrm{a} 40.09 \mathrm{a}$ & $2.39 \mathrm{~b}$ & $2.61 \mathrm{a}$ & $21.53 b$ & $22.80 \mathrm{a}$ \\
\hline
\end{tabular}

Means in the same column designated by the same letter are not significantly different at $5 \%$ level

corded the highest values of number of fertile panicles hill $^{-1}$, panicle mass, seed set (\%), seed yield and harvest index (\%) in both seasons. On the other hand, the male to female row ratio $2 \mathrm{R}: 10 \mathrm{~A}$ without $\mathrm{GA}_{3}$ application gave the lowest values number of fertile panicles hill- ${ }^{-1}$, panicle mass, seed set \%, seed yield and harvest index \% in both seasons. The results are in agreement with those reported by Rahman et al. (2010) and Abo-Youssef et al. (2017).

The results in Table (9) showed that the interaction among CMS lines, doses of $\mathrm{GA}_{3}$ application for male parent and male to female ratio was significantly affected number of fertile panicles hill ${ }^{-1}$, panicle mass, seed set, seed yield and harvest index in both seasons. The highest values of number of fertile panicles hill-1 , panicle mass, seed set \%, seed yield and harvest index (\%) were obtained with the CMS line IR69625A by $300 \mathrm{~g}$ $\mathrm{GA}_{3} \mathrm{ha}^{-1}$ for male parent when male to female ratio was 2R:14A during both seasons. While the lowest values of number of fertile panicles hill ${ }^{-1}$, panicle mass, seed set, seed yield and harvest index (\%) produced by CMS line G46A when using male to female ratio 2R:10A without $\mathrm{GA}_{3}$ application in both seasons. The results are in agreement with those reported by Riaz et al. (2019); Ghoneim (2020). 
Table 9: Effect of interaction among CMS lines, doses of $\mathrm{GA}_{3}$ application for male parent and male to female ratio on panicle characteristics and yield during 2019 and 2020 seasons

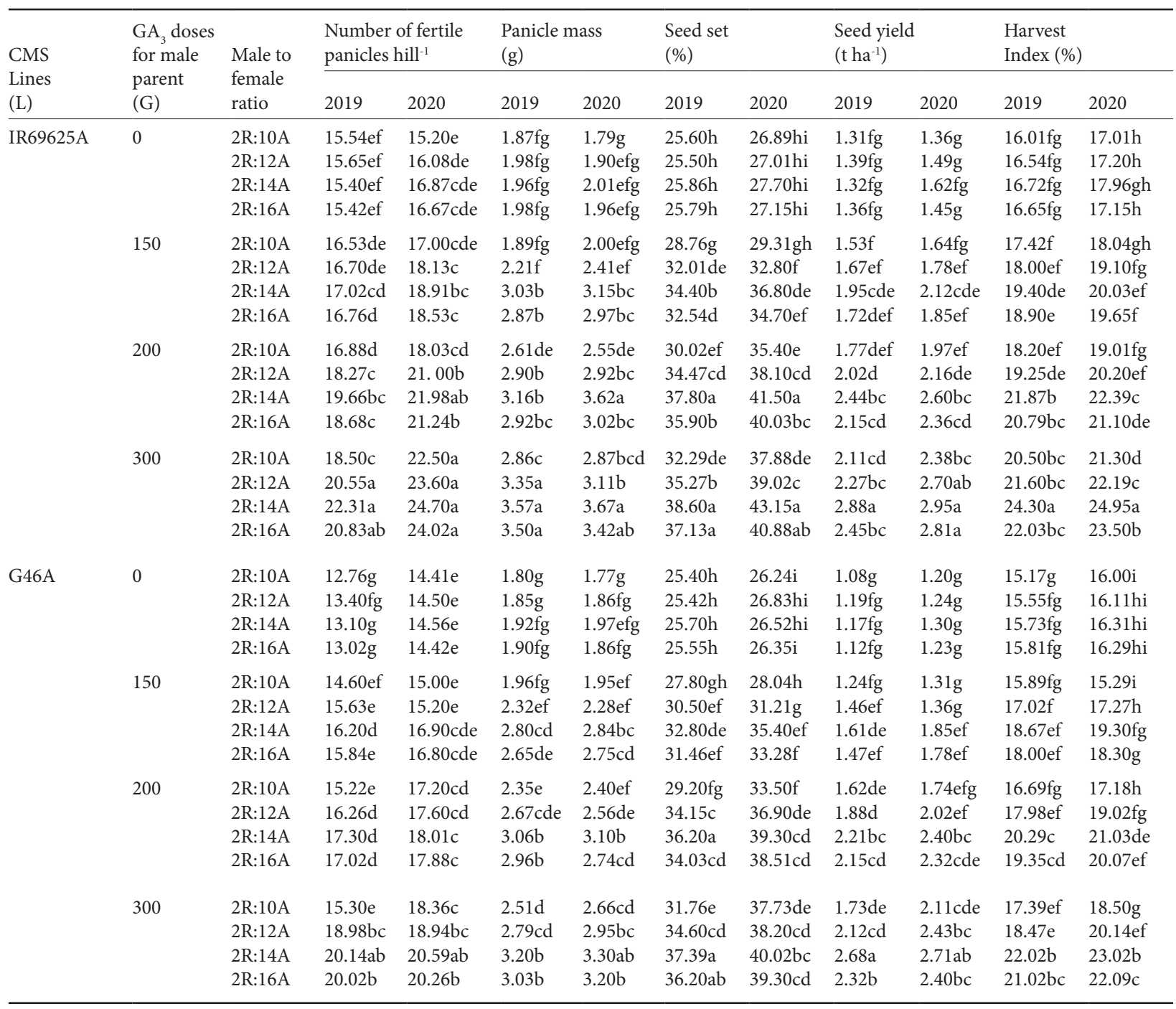

${ }^{*}=$ Significant at 0.05 level, ${ }^{*}=$ Significant at 0.01 level and NS $=$ Not significant. Means in the same column designated by the same letter are not significantly different at $5 \%$ level

\section{CONCLUSION}

The study was conducted to assess the optimal GA dose on male parent and row ratio between male to female for two CMS lines. The results indicated that, the foliar application of $\mathrm{GA}_{3}$ significantly increased panicle exsertion, seed set and seed yield of CMS lines at 300 $\mathrm{g} \mathrm{ha}{ }^{-1}$ concentration. Increase in seed yield was highly influenced by the increase in of seed set \% presumably as a result of higher panicle exsertion, wider flag leaf angle, higher degree of spikelet openings. The application of $\mathrm{GA}_{3}$ on male parent Giza 178R led to a noticeable improvement in its characteristics such as duration of floret opening, angle of floret opening, filaments exsertion, filaments length, anther length, plant height, number of tillers hill-1 ${ }^{-1}$, panicle length, plant height and panicle exsertion. The CMS line IR69625A produced the highest seed yield with application of $300 \mathrm{~g} \mathrm{GA}_{3} \mathrm{ha}^{-1}$ on male parent when male to female ratio was $2 \mathrm{R}: 14 \mathrm{~A}$. The highest values of seed yield (2.880 and $\left.2.950 \mathrm{t} \mathrm{ha}^{-1}\right)$ in 2019 and 2020 seasons were obtained by CMS line IR69625A with the application rate of $300 \mathrm{~g} \mathrm{GA}_{3}$ ha $^{-1}$ on male parent when male to female ratio was $2 \mathrm{R}: 14 \mathrm{~A}$.

\section{REFERENCES}

Abo-Youssef, M. I. (2009). The optimum row ratio and doses 
of $\mathrm{GA}_{3}$ for two rice CMS lines multiplication. Proceedings of $6^{\text {th }}$ International Plant Breeding Conference, Ismailia, Egypt: 326-338.

Abo-Youssef, M., Youssef, M., A., El Sabagh, G., Abo-Gendy, G., \& Mohamed, A. (2017). Enhancing seed yield of hybrid rice by maintaining row ratio and dosages of gibberellic acid. Cercetări Agronomice în Moldova, 1(169), 31-45. https://doi.org/10.1515/cerce-2017-0003

Ehsan, Sehsan, S., \& Robert, C. S. (2019). Hybrid Rice Technology. University of Arkansas Agricultural Experiment Station Research, USA. p. 16-20.

Gaballah, M. M. (2004). Studies on hybrid rice seed production. M.Sc. Thesis, Fac. Agric., Kafr El-Sheikh, Tanta Univ, Egypt.

Gaballah, M. M., El-Ezz, A.A., Ghoneim, A. M., Yang, B., \& Xiao, L. (2021). Exploiting heterosis and combining ability in two-line hybrid rice. Acta Agriculturae Slovenica, 117(1), 1-16. https://doi.org/10.14720/aas.2021.117.1.1847

Gavino, B. R., Pi, Y., \& Abonjr, C.C (2008). Application of gibberellic acid $\left(\mathrm{GA}_{3}\right)$ in dosage for three hybrid rice seed production in the Philippines. Journal of Agricultural Tech nology, 4(1), 183-192.

Gomez, K.A., \& Gomez, A. A. (1984). Statistical Procedures for Agricultural Research. $2^{\text {nd }}$ Ed. John Wiley and Sons, Inc. New York, USA.

Ghoneim, A. M. (2020). Soil nutrients availability, rice productivity and water saving under deficit irrigation conditions. Journal of Plant Production, Mansoura University, 11(1), 7-16. https://doi.org/10.21608/jpp.2020.77983

Hamad, H. Sh. (2018). Impact of male to female ratio, flag leaf clipping and time of $\mathrm{GA}_{3}$ application on hybrid rice seed productivity. Egyptian Journal of Plant Breeding, 22(2), 277-290.

Hamad, H. Sh., Gaballah, M.M., El Sayed, A.A.\& El Shamey, E. A.Z. (2015). Effect of $\mathrm{GA}_{3}$ doses and row ratio on cytoplasmic male sterile line seed production in rice. The 9th Plant Breed Intern Conf, 7-8 Sep., Banha. Egyptian Journal of Plant Breeding, 19(3), 155-167.

Hedden, P. \& Phillips, A.L. (2000). Gibberellin metabolism: New insights revealed by the genes. Trends in Plant Science, 5(12), 523-530. https://doi.org/10.1016/S13601385(00)01790-8

Lu, Z.M. (1994). Studies on Hybrid Rice Seed Production system. Hybrid Rice, 3-4, 52-54.

Page, A.L., Miler, R. H., \& Keeney, D. R. (1982). Methods of Soil Analysis, part 2. Chemical and microbiological properties. Agronomy monograph No. 9, pp. 539-624.
Pan, S., Rasul, F., Li, W., Tian, H., Mo, Z., Duan, M., \& Tang, X. (2013). Roles of plant growth regulators on yield, grain qualities and antioxidant enzyme activities in super hybrid rice (Oryza sativa L.). Rice, 16(6), 9-14. https://doi. org/10.1186/1939-8433-6-9

Rahman, M. H., Ali, M.H., Hasan, M. J., Kulsum, M. U., \& Khatun, M. M. (2010). Outcrossing rate in row ratio of restorer and CMS lines for hybrid rice seed production. Eco-friendly Agriculture Journal, 3(5), 233-236.

Riaz, M., Muhammad, I., Tahir, T., Muhammad, S., \& Ahsan, R. (2019). Influence of $\mathrm{GA}_{3}$ on seed multiplication of CMS lines used for hybrid rice development. African Journal of Plant Science, 13(7), 195-200. https://doi.org/10.5897/ AJPS2019.1762

Sakamoto, T., Miura K., Tatsumi, T., Ueguchitanaka, M. \& Ishiyama, K. (2004). An overview of gibberellins metabolism enzyme genes and their related mutants in rice. Plant Physiology, 134(4), 1642-1653. https://doi.org/10.1104/ pp.103.033696

Sindhua, J. S. \& Kumar, I. (2002). Quality seed production in hybrid rice. Hyderabad, India. Proceedings of the $20^{\text {th }}$ Session of the International Rice Commission.

Sirajul, M., Ahmed, G. J. U., \& Julfiquar, A.W. (2005). Effect of flag leaf clipping and $\mathrm{GA}_{3}$ application on hybrid rice seed yield. Bangladesh Rice Research Institute (BRRI), 30(1), 46-47.

Sun, T. (2004). Gibberellin signal transduction in stem elongation and leaf growth. In: Plant Hormones, Biosynthesis, Signal transduction, Action, Davies P.J. (ends). Kluwer Academic Publ. Dordrecth. Netherlands. Pp: 304-320.

Tiwari, D. K., Pandey, P., Giri, S.P., \& Dwivedi, J. L. (2011). Effect of GA3 and other plant growth regulators on hybrid rice seed production. Asian Journal of Plant Sciences, 10 (2), 133-139. https://doi.org/10.3923/ajps.2011.133.139

Virmani, S.S. (2002). Advances in hybrid rice research and development in the tropics. Proceedings of the 4th International Symposium on Hybrid Rice. 14-17 May 2002, Hanoi, Vietnam, 7-20.

Virmani, S.S., CX, X., Mao, R.S. Toledo, M., Hossain, H., \& Janaiah, A. (2002). Hybrid rice seed production technology and its impact on seed industries and rural employment opportunities in Asia. International Rice Research Institute, Metro Manila, Philippines.

Zaman, F. U., Bastawisi, A.O., Draz, A.D., El-Mowafy, H. M. \& Abo-Youssef, M. I. (2002). Hybrid rice technology in Egypt: present status and future strategies. FAO, RRTC, I, $1-17$. 